\title{
Pengembangan Alat Evaluasi melalui Aplikasi Kahoot Materi Karaktekteristik Ruang dan Pemanfaatan Sumber Daya Alam dengan Penguatan Karakter Mandiri Kelas IV Mi.Rn
}

\author{
Rinda Wahyu Hidayah, Sri Murdiyah*, Tri Murti \\ Universitas Negeri Malang, Jl. Semarang No. 5 Malang, Jawa Timur, Indonesia \\ *Penulis korespondensi, Surel: sri.murdiyah@fip.um.ac.id
}

Paper received: 1-4-2021; revised: 22-4-2021; accepted: 29-4-2021

\begin{abstract}
Research on the development of evaluation tools kahoot the application of material space spatial characteristics and the utilization of natural resource themes with the Strengthening of Independent Character class IV MI.RN are valid according to material experts, media experts, as well as practical for teachers and students. The method used is a 10-step model from Borg and Gall. Evaluation tools through the application of kahoot have produced a percentage value of 93.33 percent material experts, 100 percent media experts and 97.5 percent user (teacher).
\end{abstract}

Keywords: evaluation tools; kahoot the application; IPS

\begin{abstract}
Abstrak
Penelitian pengembangan alat evaluasi melalui aplikasi kahoot materi karakteristik ruang dan pemanfaatan sumber daya alam tema dengan Penguatan Karakter Mandiri kelas IV MI.RN yang valid menurut ahli materi, ahli media, serta praktis bagi guru dan siswa. Metode yang digunakan adalah 10 langkah model dari Borg and Gall. Alat evaluasi melalui apikasi kahoot telah menghasilkan nilai persentase dari ahli materi 93,33 persen, ahli media 100 persen dan pengguna (guru) 97,5 persen.
\end{abstract}

Kata kunci: alat evaluasi; apikasi kahoot; IPS

\section{Pendahuluan}

Ilmu Pengetahuan Sosial/IPS adalah muatan yang mempelajari, menelaah, menganalisis gejala dan masalah sosial di masyarakat dengan meninjau dari berbagai aspek kehidupan atau satu perpaduan. Tujuan pendidikan IPS adalah mengembangkan kemampuan siswa dalam menguasai ilmu social untuk menggapai tujuan pendidikan yang tinggi (Susanto, 2014). Tujuan IPS tersebut dapat terealisasikan apabila pengembangan potensi siswa dapat dilaksanakan dengan baik.

Dalam meningkatkan pemahaman siswa dengan diberikan rangsangan agar siswa menjadi rajin belajar. Membuat evaluasi yang berbeda dapat menjadikan pola pikir siswa menjadi berkembang. Pembelajaran IPS yang dilaksanakan menjadi menarik. Agar pola pikir siswa menjadi berkembang yaitu sering latihan mengerjakan soal. Alat evaluasi yang baik apabila dapat mengevaluasi dengan hasil yang sesuai. Dengan adanya teknologi dapat menjadi media pembelajaran yang menarik melalui aplikasi pembelajaran serta mempermuda guru dalam menyampaikan pesan kepada siswa (Fitri, 2017).

Berdasarkan hasil wawancara pada guru kelas IV MI.RN terdapat beberapa masalah evaluasi hasil belajar yang dilakukan oleh guru kelas IV dibuat tertulis belum secara online. Belum adanya evaluasi yang praktis pada pembelajaran IPS. Guru juga belum menerapkan alat evaluasi berupa kuis menggunakan Aplikasi Kahoot untuk mengembangkan pola pikir siswa 
agar siswa dapat berpikir mandiri. Belum dimanfaatkannya secara maksimal teknologi informasi dan komunikasi yang tersedia. Fasilitas yang dimiliki sekolah yaitu tersedianya jaringan Wifi. Sementara siswa kelas IV masih belum terbiasa melakukan evaluasi online. Sehingga perlu membiasakan siswa untuk mengerjakan soal- soal online untuk mengukur pemahaman terhadap pembelajaran yang telah dilakukan. Sedangkan hasil angket siswa kelas IV MI.RN diperoleh bahwa siswa ingin evaluasi dibuat berbeda. Siswa lebih senang jika evaluasi dibuat menggunakan game maupun secara online. Setiap siswa memiliki handpone dan senang bermain handphone.

Dengan digunakannya alat evaluasi berbasis teknologi memberi dampak yang positif, karena peserta didik akan antusias dalam pembelajaran IPS yang berlangsung, pembelajaran IPS menjadi menarik dan menyenangkan. Materi dalam pengembangan alat evaluasi ini yaitu materi IPS pada tema Cita-citaku. Peneliti mengambil materi tersebut karena belum ada alat evaluasi online. Alat evaluasi yang dikembangkan melalui Aplikasi Kahoot. Kahoot adalah aplikasi online berupa soal yang dalam bentuk Quiz, maupun True or False. Pemberian skor diberikan pada siswa yang mengikuti permainan yang menjawab benar. Sehingga memberi dampak positif pada pembelajaran IPS, karena dengan mengerjakan soal online siswa lebih tertarik. Pengembangan alat evaluasi ini untuk mendukung penguatan pendidikan karakter. Menurut Khan dalam Ali (2018) pendidikan karakter sebagai proses kegiatan yang dilakukan dengan segala daya dan upaya secara sadar dan terencana untuk mengarahkan anak didik. Pendidikan karakter adalah kegiatan secara sadar dan sungguh-sungguh untuk membimbing peserta didik agar bertindak sesui dengan landaran etis.

Permendikbud No 20 Tahun 2018 menerapkan 18 nilai karakter, salah satunya adalah mandiri. Menurut Zainuddin \& Suwarti (2017) karakter mandiri merupakan perilaku tidak tergantung pada orang lain dalam menyelesaikan tugas-tugasnya. Alat evaluasi ini untuk menguatkan katakter mandiri siswa karena evaluasi dikerjakan secara mandiri tanpa kerja sama. Alat evaluasi ini dikatakan valid apabila apabila mendapat nilai minimal 70,01\% dari hasil penilaian ahli dan pengguna. Serta dikatakan praktis apabila persentasi mencapai nilai $50 \%$ dari hasil penilaian siswa. Berdasarkan permasalahan yang dijelaskan, maka peneliti melakukan sebuah inovasi soal evaluasi online dalam penelitian yang berjudul "Pengembangan Alat Evaluasi Melalui Aplikasi Kahoot Materi Karakteristik Ruang dan Pemanfaatan Sda dengan Penguatan Karakter Mandiri Kelas IV MI.RN”.

\section{Metode}

Model penelitian dan pengembangan yang digunakan dalam penelitian ini adalah model penelitian dan pengembangan Research and Development dari Borg and Gall (dalam Sugiyono: 2018) yang terdiri dari sepuluh langkah. Langkah-langkah penelitian meliputi: 1) potensi dan masalah, 2) pengumpulan data, 3) desain produk, 4) validasi desain, 5) revisi desain, 6) uji coba, 7) revisi produk, 8) uji coba pemakaian, 9) revisi produk, 10) produksi masal.

Sumber data dalam penelitian dan pengembangan ini yaitu subjek di mana data diperoleh. Subjek dalam penelitian dan pengembangan ini terdiri dari subjek uji kelayakan yang dilakukan oleh ahli media, ahli materi, dan guru kelas IV MI.RN Pucungsari dan subjek uji produk dilakukan oleh siswa kelas IV MI.RN Pucungsari. Teknik pengumpulan data pada penelitian dan pengembangan ini yaitu melalui wawancara, angket lembar validasi, tes dan respon siswa kelas IV MI.RN Pucungsari Kabupaten Blitar. 
Teknik analisis data yang digunakan untuk menganalis instrument validasi dari ahli media, ahli materi, guru dan respon siswa menggunakan teknik analisis data secara deskriptif kuantitatif. Instrument validasi menggunakan skala linkert dengan karakteristik berisi pertanyaan dan jawaban untuk responden. Jawaban dalam skala linkert dimulai dari kriteria sangat baik sampai kurang baik yang disimbolkan dengan angka, misalnya, (1)= kurang baik, (2)= cukup, (3)= baik, (4)= sangat baik. Data kevalidan produk oleh ahli produk, ahli materi, dan guru sebagai pengguna yang diperoleh melalui instrument lembar validitas kemudian dianalisis menggunakan rumus yang merujuk dari Akbar (2015:82) sebagai berikut :

$P=\frac{X i}{X \max } X 100 \%$

Keterangan:

Vah= validiasi ahli

Tse= total skor yang dicapai

Tsh= total skor yang diharapkan

Hasil perhitungan persentase yang diperoleh dari masing-masing responden akan dimaknai dalam table dibawah ini:

Tabel 1. Kriteria hasil validasi produk

\begin{tabular}{lll}
\hline Tingkat Pencapaian (\%) & Kategori & Keputusan Uji \\
\hline $85,01-100,00$ & Sangat valid & Dapat digunakan tanpa revisi \\
$70,01-85,00$ & Cukup valid & Dapat digunakan, namun perlu direvisi kecil \\
$50,01-70,00$ & Kurang valid & Boleh digunakan dengan revisi besar \\
$01,00-50,00$ & Tidak valid & Tidak boleh dipergunakan \\
\hline
\end{tabular}

Hasil dari kriteria validasi produk tabel di atas dapat disimpulkan bahwa alat evaluasi melalui aplikasi Kahoot dapat digunakan apabila mendapat nilai minimal 70,01\%. Apabila nilai yang diperoleh kurang dari 70,01\% maka produk tersebut diperlukan revisi sebelum dapat dipergunakan. Analisis data kepraktisan produk dalam penelitian dan pengembangan ini diperoleh dari lembar instrument validitas siswa sebagai pengguna. Lembar instrumen validitas siswa menggunakan skala Guttman. Menurut Sugiyono (2015), menyatakan bahwa pada skala Guttman akan diperoleh dua opsi jawaban yang tegas, yaitu "ya" akan diperoleh nilai 1 dan "tidak" akan memperoleh jawaban 0 . Teknik analisis kepraktisan produk menggunakan rumus sebagai berikut:

Keterangan:

$\mathrm{P}=$ Presentase skor

$\mathrm{Xi}=$ Jumlah skor yang diperoleh

Xmax= Jumlah skor yang maksimal

Hasil perhitungan persentase yang diperoleh dideskripsikan dalam table dibawah ini:

Tabel 2. Kriteria kepraktisan produk

Sumber : Akbar, 2013

\begin{tabular}{ll}
\hline Presentase & Kriteria \\
\hline $75 \%-100 \%$ & Sangat Praktis \\
$50 \%-74 \%$ & Praktis \\
$25 \%-49 \%$ & Kurang Praktis \\
$1 \%-24 \%$ & Tidak Praktis \\
\hline
\end{tabular}


Berdasarkan tabel kriteria produk alat evaluasi melalui aplikasi Kahoot dapat dikatakan praktis apabila presentasi mencapai nilai 50\%. Apabila produk alat evaluasi belum mencapai presentase diatas $50 \%$, maka perlu adanya revisi untuk mencapai presentase yang ditentukan.

\section{Hasil dan Pembahasan}

\subsection{Hasil}

Data validasi dan evaluasi dari ahli materi menyatakan setuju dengan spesifikasi produk Alat Evaluasi melalui aplikasi kahoot. Validator ahli materi adalah Suminah, S.Pd., M.Pd. Validasi dilaksanakan pada tanggal 24 Februari 2020. Adapun hasil validasinya adalah sebagai berikut.

Tabel 3. Hasil Validasi Ahli Materi

\begin{tabular}{|c|c|c|}
\hline No & Butir Penilaian & Skor \\
\hline A & Kelayakan Isi & \\
\hline 1 & Penyajian soal sesuai KD dan Indikator & 4 \\
\hline 2 & Soal sesuai dengan materi karakteristik ruang dan pemanfaatan SDA & 4 \\
\hline 3 & Kesesuaian kategori soal & 4 \\
\hline \multicolumn{2}{|c|}{ Skor } & 12 \\
\hline \multicolumn{2}{|c|}{ Presentase } & $100 \%$ \\
\hline $\mathrm{B}$ & Kelayakan Bahasa & \\
\hline 1 & Penggunaan bahasa memudahkan memahami soal & 4 \\
\hline 2 & Penggunaan bahasa yang santun & 4 \\
\hline \multicolumn{2}{|c|}{ Skor } & 8 \\
\hline \multicolumn{2}{|c|}{ Presentase } & $100 \%$ \\
\hline $\mathrm{C}$ & Penggunaan dan Penyajian & \\
\hline 1 & Penyajian soal mendorong siswa untuk terlibat aktif dalam pembelajaran & 4 \\
\hline 2 & Keefektifan penggunaan alat evaluasi & 4 \\
\hline Sko & & 8 \\
\hline \multicolumn{2}{|c|}{ Presentase } & $100 \%$ \\
\hline $\mathrm{D}$ & Tampilan Menyeluruh & \\
\hline 1 & Tampilan soal memberikan kesan menarik bagi siswa & 3 \\
\hline 2 & Soal sesuai dengan materi & 4 \\
\hline 3 & Tampilan soal mudah dipahami & 3 \\
\hline 4 & Tampilan soal mempermudah siswa mengerjakan soal & 3 \\
\hline 5 & Kepraktisan penggunaan alat evaluasi & 4 \\
\hline \multicolumn{2}{|c|}{ Skor } & 17 \\
\hline \multicolumn{2}{|c|}{ Presentase } & $85 \%$ \\
\hline $\mathrm{E}$ & Karakter Mandiri & \\
\hline 1 & Siswa dapat menggunakan alat evaluasi secara mandiri & 3 \\
\hline 2 & $\begin{array}{l}\text { Alat evaluasi dapat memberi kepercayaan diri siswa dalam menyelesaikan } \\
\text { evaluasi secara mandiri }\end{array}$ & 4 \\
\hline 3 & Alat evaluasi dapat menguatkan karakter mandiri & 4 \\
\hline & 11 \\
\hline \multicolumn{2}{|c|}{ Presentase } & $91,67 \%$ \\
\hline & $\begin{array}{l}\text { Total skor } \\
\text { Presentase }\end{array}$ & $\begin{array}{c}56 \\
93.33 \%\end{array}$ \\
\hline
\end{tabular}

Berdasarkan hasil penghitungan persentase kelayakan produk pada tabel 3. diperoleh hasil persentase kelayakan sebesar 93,33\% dan keputusan uji dapat digunakan tanpa revisi. Sedangkan data kualitatif berupa saran-saran dan masukan dari ahli materi terhadap produk 
Alat Evaluasi Melalui Aplikasi Kahoot adalah penambahan peta Indonesia, memperbaiki soal agar hanya terdapat satu jawaban yang benar.

Data validasi dan evaluasi dari ahli media menyatakan setuju dengan spesifikasi produk Alat Evaluasi melalui Aplikasi Kahoot pada bidang penilaian penyajian. Validator ahli media adalah Arda Purnama Putra, M.Pd. Validasi dilaksanakan pada tanggal 25 Februari 2020. Adapun hasil validasinya adalah sebagai berikut.

Tabel 4. Hasil Validasi Ahli Media

\begin{tabular}{clc}
\hline No & \multicolumn{1}{c}{ Butir Penilaian } & Skor \\
\hline A & Tampilan & \\
1 & Unsur tata letal tulisan secara harmonis memiliki kesatuan yang padu & 4 \\
2 & Ketepatan pemilihan jenis huruf & 4 \\
3 & Ketepatan pemilihan ukuran huruf & 4 \\
4 & Sajian soal menarik & 4 \\
5 & Dapat digunakan secara individu atau kelompok & 4 \\
6 & Ketepatan pemilihan huruf & 4 \\
7 & Kesesuaian karakter/ huruf & 4 \\
Skor & & 28 \\
Presentase & $100 \%$ \\
B & Bahasa & \\
1 & Kesesuaian bahasa dengan tingkat berfikir anak & 4 \\
2 & Kesantunan penggunaan bahasa & 4 \\
3 & Penggunaan kalimat efektif & 4 \\
Skor & & 12 \\
Presentase & $100 \%$ \\
C & Penggunaan dan Penyajian & \\
1 & Kreativitas penggunaan & 4 \\
2 & Kepraktisan penggunaan alat evaluasi & 4 \\
3 & Menu dan fasilitas (tombol) kuis mudah dimengerti & 4 \\
Skor & 12 \\
Presentase & $100 \%$ \\
Total skor & 52 \\
Presentase & $100 \%$ \\
\hline
\end{tabular}

Berdasarkan hasil penghitungan persentase kelayakan produk pada tabel 4. diperoleh hasil persentase kelayakan sebesarkan 100\% dapat diinterprestasikan dengan kategori sangat valid dan dapat digunakan. Sedangkan data kualitatif berupa saran-saran dan masukan dari ahli media terhadap produk pengembangan Alat Evaluasi melalui Aplikasi Kahoot adalah gambar yang ditaruh pada kahoot jangan mengarah kepada jawaban soal.

\subsection{Pembahasan}

Data validasi dan evaluasi dari pengguna menyatakan setuju dengan spesifikasi produk Alat Evaluasi melalui Aplikasi Kahoot pada bidang materi dan penyajian alat evaluasi. Validator pengguna adalah Yuni Purwaningsih, S.Pd sebagai guru kelas IV. Kegiatan validasi dilaksanakan pada tanggal 28 Februari 2020. Adapun hasil validasinya disajikan pada tabel 5. 
Tabel 5. Hasil Validasi pengguna

\begin{tabular}{|c|c|c|}
\hline No & Butir Penilaian & Skor \\
\hline A & Isi Produk & \\
\hline 1 & Alat evaluasi melalui aplikasi kahoot ini sesuai dengan KD kelas IV & 4 \\
\hline 2 & $\begin{array}{l}\text { Alat evaluasi melalui aplikasi ini sesuai dengan materi karakteristik ruang } \\
\text { dan pemanfaatan SDA }\end{array}$ & 4 \\
\hline 3 & Kesesuaian waktu dengan kategori soal & 4 \\
\hline Sko & & 12 \\
\hline \multicolumn{2}{|c|}{ Presentase } & $100 \%$ \\
\hline A & Desain Produk & \\
\hline 1 & $\begin{array}{l}\text { Langkah- langkah penerapan alat evaluasi melalui aplikasi kahoot ini } \\
\text { mudah diterapkan pada kelas IV }\end{array}$ & 4 \\
\hline 2 & $\begin{array}{l}\text { Langkah- langkah penerapan alat evaluasi melalui aplikasi kahoot ini aman } \\
\text { untuk dimainkan siswa kelas IV }\end{array}$ & 4 \\
\hline Sko & & 8 \\
\hline \multicolumn{2}{|c|}{ Presentase } & $100 \%$ \\
\hline A & Kegunaan Produk & \\
\hline 1 & $\begin{array}{l}\text { Alat evaluasi melalui aplikasi kahoot ini dapat melatih kemandirian siswa } \\
\text { dalam memecahkan masalah }\end{array}$ & 4 \\
\hline 2 & $\begin{array}{l}\text { Penerapan alat evaluasi melalui aplikasi kahoot dapat mengatasi kebosanan } \\
\text { siswa dalam belajar }\end{array}$ & 4 \\
\hline Sko & & 8 \\
\hline \multicolumn{2}{|c|}{ Presentase } & $100 \%$ \\
\hline A & Karakter Mandiri & \\
\hline 1 & Siswa dapat menggunakan alat evaluasi secara mandiri & 4 \\
\hline 2 & $\begin{array}{l}\text { Alat evaluasi dapat memberi kepercayaan diri siswa dalam menyelesaikan } \\
\text { evaluasi secara mandiri }\end{array}$ & 3 \\
\hline 3 & Alat evaluasi dapat menguatkan karakter mandiri & 4 \\
\hline \multicolumn{2}{|c|}{ Skor } & 11 \\
\hline \multirow{3}{*}{\multicolumn{2}{|c|}{ Presentase }} & $91,666 \%$ \\
\hline & & 39 \\
\hline & & $97,5 \%$ \\
\hline
\end{tabular}

Berdasarkan hasil penghitungan persentase kelayakan produk pada tabel 5. diperoleh hasil persentase kelayakan sebesar 97,5\% untuk itu dapat diinterprestasikan dengan predikat sangat praktis. Sedangkan data kualitatif berupa saran-saran dan masukan dari guru kelas sebagai pengguna produk Alat Evaluasi melalui Aplikasi Kahoot adalah (1) memperhatikan tingkat kesulitan butir soal dengan waktu.

Sasaran uji coba terbatas yaitu siswa kelas IV yang berjumlah 3 siswa. Uji coba terbatas dilakukan melalui kegiatan pengenalan Alat Evaluasi Melalui aplikasi Kahoot, pengisian identitas, mengerjakan instrumen tes, dan mengisi angket alat evaluasi oleh siswa. Adapun hasil angket kepraktisan siswa yang dilaksanakan pada uji coba terbatas disajikan pada tabel 6. 
Tabel 6. Hasil revisi produk alat evaluasi melalui aplikasi kahoot.

\begin{tabular}{|c|c|c|c|c|}
\hline \multirow[t]{2}{*}{ No. } & \multirow[t]{2}{*}{ Pertanyaan } & \multicolumn{2}{|c|}{ Frekuensi } & \multirow[t]{2}{*}{ Total } \\
\hline & & Ya & Tidak & \\
\hline 1. & $\begin{array}{l}\text { Apakah tampilan soal evaluasi menggunakan aplikasi } \\
\text { Kahoot ini menarik? }\end{array}$ & 3 & & 3 \\
\hline 2. & $\begin{array}{l}\text { Apakah bahasa yang digunakan dalam soal ini mudah } \\
\text { dimengerti? }\end{array}$ & 2 & 1 & 3 \\
\hline 3. & $\begin{array}{l}\text { Apakah soal evaluasi ini dapat menguji seberapa jauh } \\
\text { pemahaman kamu tentang materi yang sudah diajarakan } \\
\text { di sekolah? }\end{array}$ & 3 & & 3 \\
\hline 4. & $\begin{array}{l}\text { Apakah soal evaluasi menggunakan aplikasi Kahoot } \\
\text { meningkatkan motivasi belajar? }\end{array}$ & 2 & 1 & 3 \\
\hline 5. & $\begin{array}{l}\text { Apakah soal evaluasi yang dikemas menggunakan aplikasi } \\
\text { menarik minatmu dalam mengerjakan soal? }\end{array}$ & 3 & & 3 \\
\hline 6. & $\begin{array}{l}\text { Apakah soal evaluasi ini cocok digunakan dalam evaluasi } \\
\text { pembelajaran? }\end{array}$ & 3 & & 3 \\
\hline 7. & $\begin{array}{l}\text { Apakah kamu dapat menjawab soal evaluasi sendiri tanpa } \\
\text { bertanya kepada orang lain? }\end{array}$ & 3 & & 3 \\
\hline 8. & $\begin{array}{l}\text { Ketika kamu mengalami kesulitan apakah kamu mencari } \\
\text { sendiri jawabannya? }\end{array}$ & 3 & & 3 \\
\hline 9. & $\begin{array}{l}\text { Apakah kamu menyelesaikan sendiri semua soal evaluasi } \\
\text { ini secara mandiri? }\end{array}$ & 3 & & 3 \\
\hline 10 & $\begin{array}{l}\text { Apakah kamu merasa lebih percaya diri untuk menjawab } \\
\text { soal secara mandiri menggunakan alat evaluasi ini? }\end{array}$ & 3 & & 3 \\
\hline & Jumlah & 28 & 2 & 30 \\
\hline & Presentase & 93,33 & 6,67 & $100 \%$ \\
\hline
\end{tabular}

Berdasarkan tabel 6. bahwa penilaian produk pada setiap aspek mendapat hasil ratarata sebesar 93,33\% dengan kriteria dapat digunakan tanpa revisi.

Sasaran uji coba pemakaian yaitu siswa kelas IV yang berjumlah 15 siswa. Uji coba terbatas dilakukan melalui kegiatan pengenalan Alat Evaluasi Melalui aplikasi Kahoot, pengisian identitas, mengerjakan instrumen tes, dan mengisi angket instrumen tes oleh siswa. Adapun hasil angket kepraktisan siswa yang dilaksanakan pada uji coba pemakaian adalah sebagai berikut.

Tabel 7. Hasil angket kepraktisan siswa

\begin{tabular}{|c|c|c|c|c|}
\hline \multirow[t]{2}{*}{ No. } & \multirow[t]{2}{*}{ Pertanyaan } & \multicolumn{2}{|c|}{ Frekuensi } & \multirow[t]{2}{*}{ Total } \\
\hline & & Ya & Tidak & \\
\hline 1. & $\begin{array}{l}\text { Apakah tampilan soal evaluasi menggunakan aplikasi } \\
\text { Kahoot ini menarik? }\end{array}$ & 15 & & 15 \\
\hline 2. & $\begin{array}{l}\text { Apakah bahasa yang digunakan dalam soal ini mudah } \\
\text { dimengerti? }\end{array}$ & 13 & 2 & 15 \\
\hline 3. & $\begin{array}{l}\text { Apakah soal evaluasi ini dapat menguji seberapa jauh } \\
\text { pemahaman kamu tentang materi yang sudah diajarakan di } \\
\text { sekolah? }\end{array}$ & 15 & & 15 \\
\hline 4. & $\begin{array}{l}\text { Apakah soal evaluasi menggunakan aplikasi Kahoot } \\
\text { meningkatkan motivasi belajar? }\end{array}$ & 15 & & 15 \\
\hline 5. & $\begin{array}{l}\text { Apakah soal evaluasi yang dikemas menggunakan aplikasi } \\
\text { menarik minatmu dalam mengerjakan soal? }\end{array}$ & 14 & 1 & 15 \\
\hline 6. & $\begin{array}{l}\text { Apakah soal evaluasi ini cocok digunakan dalam evaluasi } \\
\text { pembelajaran? }\end{array}$ & 14 & 1 & 15 \\
\hline
\end{tabular}




\begin{tabular}{|c|c|c|c|c|}
\hline 7. & $\begin{array}{l}\text { Apakah kamu dapat menjawab soal evaluasi sendiri tanpa } \\
\text { bertanya kepada orang lain? }\end{array}$ & 12 & 3 & 15 \\
\hline 8. & $\begin{array}{l}\text { Ketika kamu mengalami kesulitan apakah kamu mencari } \\
\text { sendiri jawabannya? }\end{array}$ & 15 & & 15 \\
\hline 9. & $\begin{array}{l}\text { Apakah kamu menyelesaikan sendiri semua soal evaluasi } \\
\text { ini secara mandiri? }\end{array}$ & 15 & & 15 \\
\hline 10 & $\begin{array}{l}\text { Apakah kamu merasa lebih percaya diri untuk menjawab } \\
\text { soal secara mandiri menggunakan alat evaluasi ini? }\end{array}$ & 13 & 2 & 15 \\
\hline & Jumlah & 141 & 9 & 150 \\
\hline & Presentase & $94 \%$ & $6 \%$ & $100 \%$ \\
\hline
\end{tabular}

Validasi ahli materi terhadap alat evaluasi melalui aplikasi kahoot meliputi kelayakan isi yang terdiri dari kesesuaian soal dengan KD dan Indikator kesesuaian soal dengan materi karakteristik ruang dan pemanfaatan sumber daya alam. Aspek kelayakan bahasa yang terdiri dari penggunaan bahasa yang memudahkan memahami soal, penggunaan bahasa yang santun. Aspek penggunaan dan penyajian penyajian soal yang mendorong siswa aktif, dan keefektifan penggunaan alat evaluasi. Aspek tampilan menyeluruh terdiri dari tampilan soal yang menarik, kesesuaian soal dengan materi, tampilan soal yang mudah dipahami, tampilan soal mempermudah dalam pengerjaan soal, dan kepraktisan penggunaan alat evaluasi. Aspek mandiri terdiri dari penggunaan alat evaluasi secara mandiri, kepercayaan diri menyelesaikan soal secara mandiri, dan alat evaluasi menguatkan karakter mandiri.

Validasi ahli media terhadap alat evaluasi melalui aplikasi kahoot meliputi aspek tampilan yang terdiri dari unsur tata letak tulisan, ketepatan pemilihan jenis huruf, ketepatan pemilihan ukuran huruf, sajian soal yang menarik, dapat digunakan secara individu maupun kelompok,ketepatan pemilihan huruf dan kesesuaian pemilihan karakter. Aspek bahasa meliputi kesesuain bahasa dengan tingkat berfikir anak, kesantunan bahasa,dsn penggunaan kalimat yang efektif. Aspek penggunaan dan penyajian terdiri dari kreativitas penggunaan, kepraktisan penggunaan alat evaluasi, serta menu dan tombol kuis mudah dimengerti.

Validasi yang sudah dilakukan oleh guru kelas IV MI. RN Pucungsari sebagai pengguna alat evaluasi menilai menilai aspek isi produk yang terdiri dari kesesuaian KD dengan alat evaluasi, kesesuaian materi dengan alat evaluasi, dan kesesuaian waktu dengan kategori soal. Aspek desain produk berisi tentang kemudahan penerapan langkah- langkah alat evaluasi pada siswa kelas IV, keamanan alat evaluasi untuk dimainkan siswa kelas IV. Aspek kegunaan produk terdiri dari alat evaluasi melalui aplikasi kahoot dapat melatih kemandirian siswa dalam memecahkan masalah, dan alat evaluasi ini dapat mengatasi kobosanan siswa dalam belajar. Aspek kemandirian meliputi siswa dapat menggunakan alat evaluasi sevara mandiri, memberikan kepercayaan diri siswa untuk menyelesaikan evaluasi secara mandiri dan dapat menguatkan karakter mandiri.

Uji coba terbatas dilakukan kepada 3 siswa kelas IV untuk menilai kepraktisan produk. Uji coba ini juga digunakan untuk meminimalisir kekurangan produk sebelum melakukan uji coba pemakaian pada siswa yang lebih banyak. Hasil dari respon siswa pada uji coba terbatas mendapat penilaian produk sebesar 93,33\%. Hasil penilaian diinterpretasikan sesuai dengan tabel 3.6 tentang kriteria kepraktisan produk menurut Akbar (2015) bahwa 50\% - 74\% termasuk praktis dan $75 \%-100 \%$ produk termasuk kriteria sangat praktis. Berdasarkan pendapat tersebut penilaian kepraktisan pada uji terbatas yang mendapat penilaian $93,33 \%$ dan masuk kriteria sangat praktis. 
Uji coba pemakaian dilakukan pada siswa kelas IV sebanyak 15 siswa. Menurut Akbar (2015) bahwa 50\% - 74\% termasuk praktis dan 75\% - 100\% produk termasuk kriteria sangat praktis. Berdasarkan pendapat diatas dan hasil uji pemakaian memperoleh nilai kepraktisan sebesar 94\%, maka produk alat evalausi melalui aplikasi kahoot masuk pada kriteria sangat praktis. Berdasarkan hasil uji coba pemakaian siswa menggunakan alat evaluasi melalui aplikasi kahoot dengan antusias, siswa sangat serius mengerjakan soal yang ada. Siswa tertarik dengan soal yang disajikan melalui aplikasi. Karakter mandiri juga telah muncul pada penggunaan alat evaluasi melalui aplikasi kahoot. Siswa menunjukkan karakter mandiri pada saat mengerjakan, terlihat ketika mereka berusaha mengerjakan soal sendiri tanpa bertanya kepada teman, dan pandangan hanya terfokus pada hp yang berisi soal.

\section{Simpulan}

Berdasarkan hasil penelitian dan pengembangan dapat disimpulkan bahwa Alat evaluasi melalui aplikasi kahoot tema cita-citaku dengan penguatan karakter mandiri pada kelas IV telah menghasilkan produk yang valid menurut ahli dan pengguna, praktis menurut siswa, serta mengetahui kualitas instrumen tes meliputi validitas, reliabilitas, tingkat kesukaran, dan daya pembeda. Hasil validasi dari ahli materi memperoleh persentase kelayakan sebesar 93,33\% masuk ke dalam rentang 85,01\% - 100,00\%, untuk itu dapat diinterprestasikan dengan kategori sangat valid dan keputusan uji dapat digunakan tanpa revisi. Hasil validasi ahli media memperoleh persentase kelayakan sebasar $100 \%$ masuk ke dalam rentang $85,01 \%$ - 100,00\%, untuk itu dapat diinterprestasikan dengan kategori sangat valid dan dapat digunakan. Hasil validasi dari pengguna memperoleh persentase kelayakan sebesar 97,5\% masuk ke dalam rentang 85,01\% - 100,00\%, untuk itu dapat diinterprestasikan dengan predikat sangat praktis. Hasil angket kepraktisan siswa memperoleh persentase $94 \%$ dengan kriteria dapat digunakan tanpa revisi.

\section{Daftar Rujukan}

Akbar, S. (2015). Instrumen Perangkat Pembelajaran. Bandung: PT. Remaja Rosdakarya.

Arikunto, S. (2013). Dasar-dasar Evaluasi Pendidikan (edisi 2). Jakarta: PT Bumi Aksara.

Fitri, R. (2017). Penggunaan Platform Kahoot Dalam Menumbuhkan Jiwa Kompetitif Dan Kolaboratif Anak. Jurnal Anak Usia Dini Dan Pendidikan Anak Usia Dini, 3, 438-2599.

Sudjana, N. (2009). Penilaian Hasil Belajar Proses Belajar Mengajar. Bandung: Pt Remaja Rosdakarya.

Susanto, A. (2014). Pengembangan Pembelajaran IPS di SD. Kencana.

Fauzi, A., Zainuddin, Z., \& Atok, R. (2018). Penguatan karakter rasa ingin tahu dan peduli sosial melalui discovery learning. Jurnal Teori dan Praksis Pembelajaran IPS, 2(2), 83-93. 